\title{
THE URINARY EXCRETION OF 5-HYDROXYINDOLE- ACETIC ACID IN PATIENTS WITH MENOPAUSAL FLUSHING
}

\author{
BY \\ N. R. ROWELL AND JEAN W. SUMMERSCALES \\ From the Departments of Dermatology and Chemical Pathology, the University of Leeds
}

(RECEIVED FOR PUBLICATION JUNE 13, 1960)

The 24-hour urinary excretion of 5-hydroxyindoleacetic acid in women with post-menopausal flushing attacks was compared with that of a control group of post-menopausal women without flushing attacks. The results were normal in the women with post-menopausal flushing, and it is concluded that 5-hydroxytryptamine is not a factor in the pathogenesis of post-menopausal flushing.

The cause of the intermittent facial flushing which occurs frequently in some menopausal women is unknown. Flushing of the face is also a feature of metastasizing carcinoid tumours in which there is an excess of circulating 5-hydroxytryptamine, which is rapidly metabolized by monoamine oxidase to 5-hydroxyindoleacetic acid and is excreted in excess in the urine. Intravenous 5-hydroxytryptamine causes flushing and other clinical manifestations of the carcinoid syndrome (Schneckloth, Page, Del Greco, and Corcoran, 1957).

Flushing of the face is also frequent in rosacea, but there is no increase in the urinary excretion of 5-hydroxyindoleacetic acid (Rowell and Summerscales, 1960).

\section{Materials and Methods}

Twelve patients with typical menopausal flushing attacks were compared with a similar group of menopausal women who did not have flushing attacks. Details are given in Table I. The 5-hydroxyindoleacetic acid content was estimated by the method of Hanson and Serin (1955) on $4 \mathrm{ml}$. of a 24-hour specimen of urine, collected with glacial acetic acid as preservative (MacFarlane, Dalgliesh, Dutton, Lennox, Nyhus, and Smith, 1956). Readings were made on a "unicam"

TABLE I

DETAILS OF POST-MENOPAUSAL WOMEN STUDIED

\begin{tabular}{|c|c|c|}
\hline & $\begin{array}{l}\text { Women with } \\
\text { Flushing Attacks }\end{array}$ & $\begin{array}{l}\text { Women without } \\
\text { Flushing Attacks }\end{array}$ \\
\hline $\begin{array}{l}\text { No. of cases } \quad \ldots \\
\text { Age } \quad \ldots \\
\text { Time since last period } \\
\text { Time since onset of flush- } \\
\text { ing attacks } \quad .\end{array}$ & $\begin{array}{c}12 \\
45-55 \\
7 \text { months }-4 \text { years } \\
6 \text { weeks }-4\end{array}$ & $\begin{array}{c}12 \\
48-58 \\
4 \text { months-12 years } \\
-\end{array}$ \\
\hline
\end{tabular}

S.P. 600 and the results read from a calibration curve prepared from the pure substance.

\section{Results}

These are shown in Table II. There is noo significant difference in the 24-hour urinary 5--0 hydroxyindoleacetic acid excretion between the

TABLE II

24-HOUR URINARY EXCRETION OF 5-HYDROXYINDOLEACETIC ACID IN TWO SERIES OF POST-MENOPAUSAL WOMEN WITH AND WITHOUT FLUSHING ATTACKS

\begin{tabular}{|c|c|c|}
\hline & $\begin{array}{l}\text { Women with } \\
\text { Flushing Attacks }\end{array}$ & $\begin{array}{l}\text { Women without } \\
\text { Flushing Attacks }\end{array}$ \\
\hline $\begin{array}{l}\text { Range of 24-hour urinary } \\
\text { excretion of } 5 \text {-hydroxy- } \\
\text { indoleacetic acid (mg.) } \\
\text { Mean } \quad . . \quad \ldots \quad \text {. }\end{array}$ & $\begin{array}{c}2 \cdot 1-9 \cdot 8 \\
7 \cdot 63\end{array}$ & $\begin{array}{c}4.2-11 \cdot 5 \\
7.65\end{array}$ \\
\hline
\end{tabular}

group of menopausal women who had flushes and those who did not $(P=<0.9)$. This confirms the observations of Munsick (1959), who found a normal excretion of 5-hydroxyindoleacetic acid in the urine of five patients who had been surgically castrated. In his patients the inhibition of flushing by the administration of oestrogens did not alter the excretion of 5-hydroxyindoleacetic acid.

We wish to thank Dr. F. F. Hellier and Dr. S. T. Anning for permission to investigate patients under their care, and Professor G. H. Lathe, in whose laboratory the 5-H.I.A.A. analyses were made.

\section{REFERENCES}

Hanson, A., and Serin, F. (1955). Lancet, 2, 1359.

MacFarlane, P. S., Dalgliesh, C. E., Dutton, R. W., Lennox, B. Nyhus, L. M., and Smith, A. N. (1956). Scot. med. J., 1, 148.

Munsick, R. A. (1959). Amer. J. Obstet. Gynec., 78, 147.

Rowell, N. R., and Summerscales, J. W. (1960). J. Invest. Lerm., in the press.

Schneckloth, R., Page, I. H., Del Greco, F., and Corcoran, A. C. (1957). Circulation, 16, 523. 